\title{
The effect of feeding different sources and levels of selenium on growth performance and antioxidant status of broilers raised at two different temperatures
}

by Woods, S.L., Rose, .S.P., Whiting, I.M., lonescu, C., Blanchard, A. and Pirgozliev, V.

Copyright, publisher and additional information: .This is the authors accepted manuscript. The published version is available via Taylor \& Francis

Please refer to any applicable terms of use of the publisher.

DOI: https://doi.org/10.1080/00071668.2020.1782350 


\section{The effect of feeding different sources and levels of selenium on growth performance and antioxidant status of broilers raised at two different temperatures}

\section{S.L. Woods , S.P. Rose , I.M. Whiting , C. Ionescu , A. Blanchard \& V. Pirgozliev}

To cite this article: S.L. Woods , S.P. Rose , I.M. Whiting , C. Ionescu , A. Blanchard \& V. Pirgozliev (2020): The effect of feeding different sources and levels of selenium on growth performance and antioxidant status of broilers raised at two different temperatures, British Poultry Science, DOI: 10.1080/00071668.2020.1782350

To link to this article: https://doi.org/10.1080/00071668.2020.1782350

Accepted author version posted online: 18 Jun 2020.

Submit your article to this journal

山 Article views: 6

Q View related articles

View Crossmark data $₫$ 
$1 \quad$ Publisher: Taylor \& Francis \& British Poultry Science Ltd

2 Journal: British Poultry Science

3 DOI: $10.1080 / 00071668.2020 .1782350$

4 The effect of feeding different sources and levels of selenium on growth performance 5 and antioxidant status of broilers raised at two different temperatures

6 S.L. WOODS ${ }^{1}$, S.P. ROSE ${ }^{1}$, I.M. WHITING ${ }^{1}$, A. BLANCHARD ${ }^{2}$, C. IONESCU ${ }^{2}$ AND V. 7 PIRGOZLIEV ${ }^{1}$

${ }^{1}$ National lnstitute of Poultry Husbandry, Harper Adams University, TF10 8NB, UK

${ }^{2}$ Pancosma, 1180 Rolle, Switzerland

Corresponding author: Dr V. Pirgozliev Email: vpirgozliev@harper-adams.ac.uk

The National Institute of Poultry Husbandry, Harper Adams University, Newport, UK.

Abstract

1.This study examined the effects of different dietary sources and levels of selenium (Se) on growth performance, hepatic and breast meat Se content, glutathione peroxidase (GSHPx) activity and total antioxidant status (TAS) in blood, when fed to broilers from 14 to 35

$21 \mathrm{~d}$ of age and reared at two different temperatures $\left(20^{\circ} \mathrm{C}\right.$ and $\left.35^{\circ} \mathrm{C}\right)$.

2. Five hundred and sixty male Ross 308 broilers were reared in a single floor pen and fed

23 the same proprietary starter diet from 0 to $14 \mathrm{~d}$ age $(229.9 \mathrm{~g} / \mathrm{kg} \mathrm{CP}$ and $12.67 \mathrm{MJ} / \mathrm{kg} \mathrm{ME}$, 24 without Se supplementation).

25 3. The experiment started at $14 \mathrm{~d}$ age, and the birds randomly assigned to 112 raised-floor 26 pens $\left(0.36 \mathrm{~m}^{2}\right.$ area, 5 birds/pen $)$. Each of the seven experimental diets were offered to birds 27 in 16 pens within four rooms. Two rooms were at $20^{\circ} \mathrm{C}$ and two rooms were maintained at $2835^{\circ} \mathrm{C}$. The experimental diets were fed from 14 to $35 \mathrm{~d}$ age and contained $214.9 \mathrm{~g} / \mathrm{kg} \mathrm{CP}$ and $13.11 \mathrm{MJ} / \mathrm{kg} \mathrm{ME}$. The experimental diets were as follows; control diet containing background Se only (0.189 mg/kg; C); low level sodium selenite (0.376 mg/kg; LSS): high 
31 level sodium selenite $(0.558 \mathrm{mg} / \mathrm{kg}$; HSS $)$; low level commercial B $\operatorname{Traxim}^{\circledR} \mathrm{Se}(0.244$

$32 \mathrm{mg} / \mathrm{kg})(\mathrm{LBT})$; high level B Traxim $^{\circledR} \mathrm{Se}(0.448 \mathrm{mg} / \mathrm{kg}$; HBT $)$; low level selenised yeast

33 (0.290 mg/kg; LSY); high level selenised yeast (0.487 mg/kg; HSY).

34 4. Birds consumed more when raised at $20^{\circ} \mathrm{C}$ compared to birds reared at $35^{\circ} \mathrm{C}(\mathrm{P} \leq 0.05)$.

35 Birds fed lower Se level reared at $35^{\circ} \mathrm{C}$ had higher weight gain versus those fed higher Se 36 level $(\mathrm{P}<0.05)$. Birds fed SY had the lowest feed intake, weight gain and $\mathrm{FCE}(\mathrm{P}<0.05)$.

37 The greatest GSH-Px activity was observed in birds fed SS diets $(\mathrm{P}<0.001)$. There were 38 interactions between diet $\mathrm{x}$ level for TAS, which were highest in birds fed LBT compared 39 to birds fed HBT $(\mathrm{P}<0.05)$. Breast Se content was higher in birds fed HSY compared to 40 LSY $(\mathrm{P}<0.001)$. The highest hepatic Se was seen in birds fed SY and lowest in $\mathrm{C}$ $41 \quad(\mathrm{P}<0.001)$.

42 5. Birds fed BT diets showed similar levels of Se to those birds fed inorganic Se, and 43 similar levels of GSH-Px to birds fed SY. Further comparative work with broilers fed BT 44 and other Se supplemented diets may elucidate the findings from this report.

46 Key words: Chickens, selenium, performance, antioxidant status, temperature.

\section{Introduction}

49 The global climate is changing, with reports that temperatures are becoming hotter (by 50 approximately $1.5^{\circ} \mathrm{C}$ during the $21^{\text {st }}$ century) and affected areas are increasing in size 51 (IPCC, 2018). A rise in temperature is an increasingly important consideration for poultry 52 producers (Nawab et al., 2018). Higher temperature negatively affects broiler performance 53 and reduces feed intake (FI), weight gain (WG) and feed conversion efficiency (FCE) 54 (Geraert et al., 1995), and increases oxidative stress (Altan et al., 2003). Oxidative stress is 55 a complex metabolic process, which involves the inability of pro-oxidants, known as free 56 radicals (FR), which are highly reactive molecules which need to be maintained below 
57 toxic levels (Sies, 2015). Free radicals are produced as by-products of normal

58 physiological processes, but when levels exceed the body's ability to neutralise them, this

59 can lead to cellular stress and, if left unchecked, can induce a state of oxidative stress

60 (Lushchak, 2014).

61 Heat stress (HS) reduces immunity by inhibiting antibody production (Mashaly et al.,

62 2004); causes a reduction in antioxidant enzymes, contributing to tissue damage, and the

63 development of oxidative stress (Lin et al., 2006; Akbarian et al., 2016). Levels of

64 oxidative stress can be measured by the presence of antioxidants, such as selenium (Se) in

65 tissue, and by examining changes in antioxidant enzyme activities, such as glutathione

66 peroxidase (GSH-Px), which is an important Se-containing enzyme (Surai and Fisinin

67 2014). Higher activity of GSH-Px can be expected in birds with higher oxidative status,

68 and, as birds experience HS, those fed higher levels of Se would be expected to have

69 higher GSH-Px to minimise the physiological development of oxidative stress (Altan et al., 70 2003).

71 Antioxidant status is determined by measuring an animal's total antioxidant status (TAS),

72 and described by Krawczuk-Rybak et al. (2012), which includes all antioxidants present in

73 body fluids (both enzymatic and non-enzymatic). As temperature increases, oxidative

74 stress can be expected to increase and the animal's overall TAS to decrease (Sarica et al.,

75 2017). The inclusion of supplementary antioxidants (in particular Se) in poultry diets have

76 been shown to be beneficial in minimising the negative impact of excessive temperatures,

77 in terms of improved performance variables (Liao et al., 2012) and resistance to oxidative

78 stress (Niu et al., 2009). Research has shown how different levels and sources of Se affect

79 these variables (Leeson et al., 2008; Woods et al., 2020) as well as in heat challenged

80 environments in quail (Sahin et al., 2008). However, research comparing different levels

81 and sources of Se in broilers reared at different temperatures is limited. Investigating

82 whether a Se source (and level) is more effective at enhancing broiler performance and/or Accepted for publication 22 April 2020 
83 oxidative status has important economic and animal welfare implications, especially as

84 birds raised in modern intensive production systems often experience stresses from a wide variety of sources (Surai, 2006). B Traxim ${ }^{\circledR}$ Se (Pancosma, 1180 Rolle, Switzerland), is a commercial, organic Se compound formed by a process which incorporates inorganic Se to

87 form a selenium proteinate, using soybean peptides as the ligand (Leeson et al., 2008; Xu 88 et al., 2015). The aims of this study were to investigate how different sources and levels of

89 Se (an inorganic sodium selenite (SS); a Se source formed by the reaction of inorganic Se on a hydrolysed soya protein B TRAXIM ${ }^{\circledR}$ Se (Pancosma, 1180 Rolle ,Switzerland) (BT) and selenised yeast (SY)), affect broiler performance variables (measured as feed intake

92 (FI), weight gain (WG) and feed conversion efficiency (FCE)), antioxidant status

93 (measured by GSH-Px activity and TAS) and the concentration of Se in breast and liver 94 tissue when broilers were reared at $20^{\circ} \mathrm{C}$ and $35^{\circ} \mathrm{C}$ from 14 to $35 \mathrm{~d}$ age.

\section{$95 \quad$ Materials and methods}

\section{Experimental diets}

97 The experiment was conducted from 14 to $35 \mathrm{~d}$ age. Seven wheat-soy-based diets were 98 offered to birds during the experiment. A basal diet, consisting of $629.5 \mathrm{~g} / \mathrm{kg}$ wheat, and $99280 \mathrm{~g} / \mathrm{kg}$ soybean meal as the main ingredients, formulated to be adequate in protein (214.9 $100 \mathrm{~g} / \mathrm{kg}$ ) and energy (13.11 MJ/kg ME) containing background Se only. The control diet had 101 no added Se (C). The rest of the diets were formulated using three different sources of Se at 102 two levels; C + $0.333 \mathrm{mg} / \mathrm{kg}$ SS (LSS); C + $0.667 \mathrm{mg} / \mathrm{kg} \mathrm{SS}(\mathrm{HSS}) ; \mathrm{C}+12.605 \mathrm{mg} / \mathrm{kg} \mathrm{BT}$ 103 (LBT); C + $25.210 \mathrm{mg} / \mathrm{kg}$ BT (HBT); C + $68.182 \mathrm{mg} / \mathrm{kg} \mathrm{SY}(\mathrm{LSY}) ; \mathrm{C}+136.364 \mathrm{mg} / \mathrm{kg} \mathrm{SY}$ 104 (HSY). All Se supplements used in the diets were provided by Pancosma (Switzerland) and 105 mixed by Target Feeds Ltd. (Whitchurch, UK). 
114 Table 1 here

115

127 determined for the experimental period. The wellbeing of the birds was checked twice 128 daily.

\section{Sample collection}

130 Birds and feed were weighed at 14 and $35 \mathrm{~d}$ age in order to determine the average daily FI, 131 WG, and FCE. At the end of the study (35 d age), one bird per pen was selected at random, 132 electrically stunned and blood was obtained in $6 \mathrm{ml}$ heparin coated tubes (Midmeds Ltd., 
133 Hertford, UK) from the jugular vein. The livers and approximately $80 \mathrm{~g}$ of the right breast

134 from each bird were excised and stored at $-20^{\circ} \mathrm{C}$ for further analysis.

\section{Laboratory analysis}

136 Selenium concentrations in liver and breast samples were determined by inductively 137 coupled plasma emission spectrometry (Optima 4300 DV Dual View ICP-OE spectrometer, 138 Perkin-Elmer, Beaconsfield, UK), as described by Tanner et al. (2002). Both the GSH-Px 139 in blood and the TAS in plasma were determined on Cobas Mira Plus auto-analyser (ABX 140 Diagnostics, Bedfordshire, UK). The GSH-Px was determined using a Ransel GSH-Px kit 141 (Randox Laboratories Ltd., Crumlin, UK) based on the method used by Paglia and 142 Valentine (1967), and the TAS in plasma was determined using a Ransel TAS kit (Randox 143 Ltd.) based on the method used by Rice-Evans and Miller (1994).

\section{Statistical analysis}

145 Data were analysed using a split plot ANOVA design (Genstat $18^{\text {th }}$ edition 3.22 for 146 Windows, IACR, Rothamsted, Hertfordshire, UK) with the main plots being temperature 147 treatment between rooms. Within rooms, the seven dietary treatments were compared in a $1481+3 \times 2$ factorial arrangement, using the model: $\mathrm{Y}=\mu+\mathrm{Ti}+\beta \mathrm{j}(\mathrm{i})+\mathrm{C}+\mathrm{Se} \mathrm{k}+\mathrm{L} 1+(\mathrm{Se} . \mathrm{L}) \mathrm{kl}+(\mathrm{T} . \mathrm{Se}) \mathrm{ik}+(\mathrm{T} . \mathrm{L}) \mathrm{il}+\varepsilon \mathrm{ikl}$

150 Where $\mu=$ overall mean; $\mathrm{T}=$ effect of temperature and $\mathrm{I}=1,2 ; \beta=$ random effect of room 151 receiving temperature $\mathrm{I}$; and $\mathrm{j}=1$ to $4 ; \mathrm{C}=$ control diet; $\mathrm{Se}=$ selenium source and $\mathrm{k}=$ $1521,2,3 ; \mathrm{L}=$ level of selenium and $\mathrm{l}=1,2 ; \varepsilon=$ random error. When $\mathrm{P}<0.05$, Tukey's multiple 153 range test was used to separate differences between the mean values of dietary treatment 154 groups. For measured variables with a diet $\mathrm{x}$ level interaction, the differences between the 155 two dietary levels were compared, using the least significant different test. 
157

158

159

160 dietary treatment.

Table 2 here

171

\section{Oxidative status}

173 Glutathione peroxidase activity was lower in birds fed the control (C) diet versus the Se

174 supplemented diets $(\mathrm{P}<0.001)$ and higher inclusion resulted in greater GSH-Px activity $175 \quad(\mathrm{P}=0.006$; Table 3$)$.

There were diet $\mathrm{x}$ level interactions for TAS $(\mathrm{P}=0.043)$ and Se in breast $(\mathrm{P}<0.001)$. Birds

177 fed LBT had higher TAS compared to those fed HBT and the rest of the diets $(\mathrm{P}=0.043)$.

\section{Selenium tissue accumulation}

179 Selenium concentration in the liver was highest in those birds fed SY diets, and lowest in 180 birds fed diet $\mathrm{C}(\mathrm{P}<0.001)$ and higher product level contained the highest liver Se $181 \quad(\mathrm{P}<0.001 ;$ (Table 3). 
Table 3 here

\section{Discussion}

This study compared three different sources of selenium - inorganic, organic and a source

187 formed by the reaction of inorganic Se with a hydrolysed soya protein. The metabolism

188 and absorption of Se is complex and differs between forms. Sodium selenite is absorbed by passive diffusion across the gut wall and is easily incorporated into seleno-proteins

190 (Wolffram et al., 1989). Selenised yeast is absorbed in the intestine by an active transport

191 mechanism using methionine transporters and enters the body's methionine pool (Burk and

192 Hill, 2015). From there it can directly be incorporated into proteins through the

193 replacement of methionine, or it can be converted to selenocysteine (SeCys), which

194 subsequently may be cleaved to form selenide (Oliveira et al., 2014). Few studies have

195 reported on the mechanism of absorption for BT, but Leeson et al. (2008) has shown it to

196 accumulate more in lipid-associated components compared to SY, which is deposited more

197 readily in proteins.

198 There is divided opinion as to whether feeding organic Se to chickens improves FI and 199 WG, compared to inorganic Se (Yang et al., 2012; Mohapatra et al., 2014) or whether the 200 level of Se is more important than source in affecting performance (Choct et al., 2004;

201 Oliveira et al., 2014). Comparable broiler studies with BT are limited, but results from 202 Jang et al. (2010) agreed with the findings from the current study, whereby diets 203 containing BT had higher FI compared to those supplemented with SS and SY when they 204 were fed to pigs. In the current study, growth performance variables (FI and FCE), were 205 not affected by Se level, which was in agreement with findings by Peric et al. (2009) when 206 comparing (0.0 and $0.3 \mathrm{ppm})$ levels of SS and SY diets fed to broilers. 
207 Similar to others (Quinteiro-Filho et al., 2010; Habibian et al., 2014) the authors of the

208 current study found that birds reared under higher temperatures consumed and weighed

209 less than those reared at standard temperatures. This was unsurprising, as feathers and the

210 absence of sweat glands (Herreid and Kessel, 1967) makes birds prone to the effects of HS.

211 Broilers are particularly susceptible because they are bred to have a high FI and fast

212 growth rate, which increases heat production during metabolism. Consuming less feed

213 enables a reduction in metabolic heat production (Teeter, 1996). The reason for the finding

214 that birds reared at $35^{\circ} \mathrm{C}$ and fed low levels of Se had higher weight gain compared to

215 those fed high Se levels was not entirely clear, but could have reflected the amount of feed

216 consumed, because FI was less for higher Se levels in birds raised at $35^{\circ} \mathrm{C}$, although this

217 was not significant. Reports by Wang and $\mathrm{Xu}$ (2008) found no difference in feed efficiency

218 for birds fed SS or SY, which disagreed with findings from the current study, but no

219 differences were found when comparing diet level, which was similarly reported by

220 Oliveira et al. (2014). The determined levels of Se in the current $\mathrm{C}$ diets were within the

221 NRC (1994) minimum broiler specifications of $0.15 \mathrm{mg} / \mathrm{kg}$ of Se, so it was deemed there

222 was sufficient Se to enable normal growth (Aviagen, 2018).

223 Oliveira et al. (2014) agreed with the current study, in that birds fed higher Se levels as

224 SY, resulted in increased deposition of Se in breast tissue. In addition, birds fed diets with

225 SY had highest Se levels in breast and liver tissue, compared to those fed SS and BT diets,

226 which agreed with Oliveira et al. (2014) and Leeson et al. (2008). However, when

227 comparing diet $\mathrm{x}$ level interactions, the increase in HSY was significant only in the breast

228 meat, and not the liver. A possible explanation for this could be due to the faster metabolic

229 rate in the liver, and the fact that the Se was in a metabolic (usable) form compared to

230 breast tissue, in which it was mainly found as SeMet, a storage form of Se. This could have

231 led to a greater fluctuation in tissue concentrations compared with breast muscle, as Se was

232 distributed to other areas in the body from the liver (Wang et al., 2010). 
233 The GSH-Px is one of at least 25 Se containing enzymes that have been identified, and,

234 because it contains Se, it is dependent on dietary intake and the corresponding Se status in

235 tissues (Surai, 2002). It has been described as being a critical factor in maintaining redox

236 balance and is important in cellular signalling and repair pathways (Cnubben et al., 2001).

237 There are conflicting reviews on whether different Se sources supplemented in poultry

238 diets increase or decrease GSH-Px activity (Choct et al., 2004; Chen et al., 2014). An

239 increase in GSH-Px activity would be expected in diets supplemented with Se and would

240 indicate a higher oxidative status (Surai, 2006). Differences in GSH-Px between birds fed

241 different Se sources have been reported, and in agreement with the current study, previous

242 reports by Leeson et al. (2008) and Dlouha et al. (2008) found lower GSH-Px activity from

243 birds fed diets from organic Se sources (SY and BT) versus those fed diets from inorganic

244 (SS) sources. However, Payne and Southern (2005) found that different sources and levels

245 of Se had no influence on GSH-Px activity. The lower GSH-Px levels in birds fed organic

246 Se have been reported by Leeson et al. (2008) as having improved oxidative stability and

247 less need for enzyme intervention. However, this is disputed by the authors of the current

248 study, because feeding all the Se supplemented diets in the present study resulted in higher

249 GSH-Px activity compared with those birds fed the C diet. Higher Se level resulted in

250 higher GSH-Px levels. The expected outcome of birds reared in higher temperatures was

251 that they would experience greater oxidative stress, and have lower GSH-Px activity.

252 However, in the current study, there was no difference between birds reared at the two

253 temperatures. These findings supported similar results found by Azad et al. (2010), and

254 Mahmoud and Edens (2003). However, Pamok et al. (2009) found GSH-Px levels in

255 broilers initially decreased at $4 \mathrm{~d}$ of age when exposed to HS, but later, at $21 \mathrm{~d}$, showed no

256 differences. This implied that the older broilers at $21 \mathrm{~d}$ had been able to adapt to the

257 increase in temperature. 
258 Total antioxidant status is a bio-marker which represents the total capacity of the cell,

259 tissue or organ to limit the damaging effects of oxidising agents. This biomarker is used to

260 determine an animal's antioxidant status, with an increase in TAS indicating higher

261 antioxidant status (Hameed et al., 2017). In the current study, interactions between diets $\mathrm{x}$

262 level showed that birds fed LBT had higher TAS compared to other diets. Generally,

263 higher Se level increased TAS, except in BT fed birds where birds fed LBT had higher

264 TAS compared with birds fed HBT. The reason for this was unclear, but all diets

265 containing supplemented Se had greater TAS and therefore higher oxidative status

266 compared to birds fed diet C. Similar findings for increasing antioxidant status were

267 reported by others (Jang et al., 2014) when birds were fed ascorbic acid (vitamin C) or

268 probiotics (Capcarova et al., 2010) to broilers. However, some researchers found that

269 oxidative status (measured by TAS or GSH-Px levels) remained unchanged when broilers

270 were supplemented with antioxidants such as alpha tocopherol (vitamin E) (Voljc et al.,

271 2011), Se or essential oils (thyme) as reported by Placha et al. (2014), or dihydroquercetin

272 (Pirgozliev et al., 2019). Increased knowledge about which dietary antioxidants improve

273 oxidative status will help poultry producers in making important economic decisions when

274 they are formulating poultry diets.

276 Conclusions

277 Broilers raised at higher temperatures consumed and weighed less. Weight gain was

278 greatest in birds fed higher product level and raised at $20^{\circ} \mathrm{C}$, but increasing product level

279 decreased weight gain at $35^{\circ} \mathrm{C}$, resulting in interactions. All birds fed Se supplemented

280 diets had higher GSH-Px versus the control, indicating better antioxidant status. Birds fed

281 diets with SY had greater levels of Se in breast tissue and liver tissue, and birds fed the

282 control diets had the least amount. The B TRAXIM ${ }^{\circledR}$ selenium generally behaved like 
inorganic selenium, because it did not increase levels of Se in tissues in the same way as the organic form. However, it resulted in the same levels of GSH-Px activity as organic

SY, which indicated it was less freely available than sodium selenite. Further work comparing diets supplemented with B TRAXIM ${ }^{\circledR}$ Se and other selenium sources on broiler performance and antioxidant status are required to confirm the findings in this report.

\section{Acknowledgements}

Special thanks to Richard James and Rosalind Crocker for their technical support.

\section{Funding}

This work was supported by Pancosma, Switzerland and Harper Adams University.

\section{References}

AKBARIAN, A., J., MICHIELS, J., DEGROOTE, M., MAJDEDDIN, A., GOLIAN, and

S. DE SMET. 2016. “Association between Heat Stress and Oxidative Stress in Poultry:

Mitochondrial Dysfunction and Dietary Interventions with Phytochemicals." Journal of Animal Science and Biotechnology 7: 4-14. doi.org/10.1186/s40104-016-0097-5.

ALtAN, O., A., PABBUCCUOGLU, A., ALtAN, S., KONYALIOGLU, and H. BAYRAKTAR. 2003. "Effect of Heat Stress on Oxidative Stress, Lipid Peroxidation and Some Stress Parameters in Broilers.” British Poultry Science 44: 545-550.

doi.org/10.1080/00071660310001618334.

AVIAGEN 2018. "Ross 308 Broiler: Nutrition Specifications.” Accessed September 2019. http://en.aviagen.com/assets/Tech_Center/Ross_Broiler/Ross308BroilerNutritionSpecs201 4-EN.p

AZAD, M.A.K., M., KIKUSATO, T., MAEKAWA, H., SHIRAKAWA, and M. TOYOMIZU. 2010. "Metabolic Characteristics and Oxidative Damage to Skeletal Muscle Accepted for publication 22 April 2020 
311 in Broiler Chickens Exposed to Chronic Heat Stress." Comparative Biochemistry and 312 Physiology Part A: 401-406. doi.org/10.1016/j.cbpa.2009.12.011.

313 BURK, F. and K.E. HILL. 2015. "Regulation of Selenium Metabolism and Transport.” 314 Annual Review of Nutrition 35 (1): 109-134. doi.10.1146/annurev-nutr-071714-034250.

315 CAPCAROVA, M., J., WEIS, C., HRNCAR, A., KOLESAROVA, and G. PAL. 2010.

316 "Effect of Lactobacillus fermentum and Enterococcus faecium Strains on Internal Milieu, 317 Antioxidant Status and Body Weight of Broiler Chicks.” Journal of Animal Physiology 318 and Animal Nutrition 94: 215-224. doi.org/10.1111/j.1439-0396.2010.01010.x.

319 CHEN, G., J., WU, and C. LI. 2014. "Effect of Different Selenium Sources on Production 320 Performance and Biochemical Parameters of Broilers." Journal of Animal Physiology and 321 Animal Nutrition 98: 747-754. doi.org/10.1111/jpn.12136.

322 CHOCT, M., NAYLOR, A.J., REINKE, N. 2004. "Selenium Supplementation Affects 323 Broiler Growth Performance, Meat Yield and Feather Coverage." British Poultry Science 32445 (5): 677-683. doi.org/10.1080/00071660400006495.

325 CNUBBEN, N.H.P., M.C.M., RIETJENS, H., WORTELBOER, J., VAN ZANDEN, and 326 P.J. VAN BLADEREN. 2001. "The Interplay of Glutathione Related Processes in 327 Antioxidant Defense.” Environmental Toxicology and Pharmacology 10: 141-152. 328 doi.org/10.1016/S1382-6689(01)00077-1.

329 DLOUHA, G., SEVCIKOVA, S., DOKOUPILOVA, A., ZITA, L., HEINDL, J., 330 SKRIVAN, M. 2008. "Effect of Dietary Selenium Sources on Growth Performance, Breast 331 Muscle Selenium, Glutathione Peroxidase Activity and Oxidative Stability in Broilers.” 332 Czechoslovakian Journal of Animal Science 53: 265-269.

$333 \mathrm{http}: / /$ citeseerx.ist.psu.edu/viewdoc/download?doi=10.1.1.625.8483\&rep=rep1\&type. 334 GERAERT, P.A., J.C.F., PADILHA, and S. GUILLAUMIN. 1995. "Metabolic and 335 Endocrine Changes Induced by Chronic Heat Exposure in Broiler Chickens: Growth 
336 Performance, Body Composition and Energy Retention.” British Journal of Nutrition 7(2): 195-204. doi.org/10.1017/BJN19960124.

HABIBIAN, M., GHAZI, S., MOEINI, M.M., ABDOLMOHAMMODI, A. 2014. “Effects

of Dietary Selenium and Vitamin E on Immune Response and Biological Blood Parameters

340 of Broilers Reared Under Thermoneutral or Heat Stressed Conditions." International

341 Journal of Biometeorology 58: 741-752. doi.org/10.1007/s00484-013-0654-y.

HAMEED, M.R., M.Z., KHAN, M.K., SALEEMI, A., KHAN, M., AKHTAR, Z.,

HASSAN, and Z. HUSSAIN. 2017. "Study of Ochratoxin A (OTA) - Induced Oxidative

344 Stress Markers in Broilers Chicks." Toxin Reviews 36 (94): 270-274.

345 doi.org/10.1080/15569543.2017.1303780.

346 HERREID, C.F. and B. KESSEL. 1967. "Thermal Conductance in Birds and

347 Mammals." Comparative Biochemistry and Physiology 21 (2): 405-414. doi.10.1016/0010-

$348 \quad 406 x(67) 90802-x$.

349 INTERGOVERNMENTAL PANEL ON CLIMATE CHANGE (IPCC)

350 https://www.ipcc.ch/2018/01/11/media-reports-on-the-draft-ipcc-special-report-on-global-

351 warming-of-1-5c/. [Accessed on 8 November 2018].

352 JANG, Y.D., H.B., CHOI, S., DUROSOY, P., SCHLEGEL, B.R., CHOI, and Y.Y. KIM.

353 2010. "Comparison of Bioavailability of Organic Selenium Sources in Finishing

354 Pigs." Asian-Australasian Journal of Animal Sciences 23 (7): 931-936.

355 doi.org/10.5713/ajas.2010.90619.

356 JANG, I.S., Y.H., KO, Y.S., MOON, and S.H. SOHN. 2014. "Effects of Vitamin C or E on 357 the Pro-Inflammatory Cytokines, Heat Shock Protein 70 and Antioxidant Status in Broiler

358 Chicks under Summer Conditions." Asian-Australasian Journal of Animal Sciences 27 (5): 359 749-756. doi.10.5713/ajas.2013.13852.

360 KRAWCZUK-RYBAK, M., A., PANASIUK, M., CZYGIER, K., MUSZYNSKA-

361 ROSLAN, J., WYSOCKA, and M. SZMITKOWSKI. 2012. "Total antioxidant status 
(TAS) in childhood cancer survivors." Folia Histochemica et Cytobiologica, 50 (3): 468472.

https://journals.viamedica.pl/folia_histochemica_cytobiologica/article/viewFile/19759/154 79

LEESON, S., H., NAMKUNG, L., CASTON, S., DUROSOY, and P. SCHLEGEL. 2008. "Comparison of Selenium Levels and Sources and Dietary Fat Quality in Diets for Broiler Breeders and Layer Hens.” Poultry Science 87: 2605-2612. doi.org/10.3382/ps.200800174.

LIAO, X., L., LU, S., LI, S., LIU, L., ZHANG, G., WANG, A., LI, and X. LUO. 2012. "Effects of Selenium Source and Level on Growth Performance, Tissue Selenium Concentrations, Antioxidation, and Immune Functions of Heat-Stressed Broilers.” Biological Trace Element Research 150 (1-3):158-165. doi.org/10.1007/s12011-012-9517-3.

LIN, H., E., DECUYPERE, and J. BUYSE. 2006. “Acute Heat Stress Induces Oxidative Stress in Broiler Chickens." Comparative Biochemistry and Physiology Part A: Molecular and Integrative Physiology 144 (1): 11-17. doi.org/10.1016/j.cbpa.2006.01.032.

LUSHCHAK, V.I. 2014. "Free Radicals, Reactive Oxygen Species, Oxidative Stress and its Classification." Chemico-Biological Interactions 224: 164-175. doi.org/10.1016/j.cbi.2014.10.016.

MAHMOUD, K.Z. and EDENS, F.W. 2003. "Influence of Selenium Sources on Age Related and Mild Heat Stress-Related Changes of Blood and Liver Glutathione Redox Cycle in Broiler Chickens (Gallus domesticus)." Comparative Biochemistry and Physiology Part B: Biochemistry and Molecular Biology 136 (4): 921-934. doi.org/10.1016/S1096-4959(03)00288-4.

MASHALY, M.M., G.L., HENDRICKS 3rd, M.A., KALAMA, A.E., GEHAD, A.O., ABBAS, and P.H. PATTERSON. 2004. "Effect of Heat Stress on Production Parameters 
and Immune Responses of Commercial Laying Hens." Poultry Science 83 (6): 889-894. doi.org/10.1093/ps/83.6.889.

MOHAPATRA, P., SWAIN, R.K., MISHRA, S.K., BEHERA, T., SWAIN, P., BEHURA, N.C., SAHOO, G., SETHY, K., BHOL, B.P. and DHAMA, K. 2014. "Effects of Dietary

Nano-Selenium Supplementation on the Performance of Layer Grower Birds." Asian

Journal of Animal Veterinary Advances 9 (10): 641-652. doi.10.3923/ajava.2014.641.652.

NATIONAL RESEARCH COUNCIL (NRC) 1994. Nutrient Requirements of Poultry. $9^{\text {th }}$

NAWAB, A., F., IBTISHAM, G., LI, B., KIESER, J., WU, W., LIU, Y., ZHAO, Y.,

NAWAB, K., LI, M., XIAO, and L. AN. 2018. "Heat Stress in Poultry Production:

Mitigation Strategies to Overcome the Future Challenges Facing the Global Poultry Industry." Journal of Thermal Biology 78: 131-139.

400 doi.org/10.1016/j.jtherbio.2018.08.010.

401 NIU, Z., F., LIU, Q., YAN, and L. LI. 2009. “Effects of Different Levels of Selenium on

402 Growth Performance and Immuno-Competence of Broilers under Heat Stress." Archives of

403 Animal Nutrition 63 (1): 56-65. doi.org/10.1080/17450390802611610.

404 OLIVEIRA, T.F.B., D.F.R., RIVERA, F.R., MESQUITA, H., BRAGA, E.M., RAMSO, 405 and A.G. BERTECHINI. 2014. "Effect of Different Sources and Levels of Selenium on

406 Performance, Meat Quality, and Tissue Characteristics of Broilers." Journal of Applied 407 Poultry Research 23: 15-22. doi.org/10.3382/japr.2013-00761.

408 PAGLIA, D.E., and W.N. VALENTINE. 1967. "Studies on the Quantitative and 409 Qualitative Characterization of Erythrocyte and Glutathione Peroxidase." The Journal of 410 Laboratory and Clinical Medicine $70 \quad$ (1): $\quad$ 158-169.

411 https://www.translationalres.com/article/0022-2143(67)90076-5/. 
412 PAMOK, S., W., AENGWANICH, and T. KOMUTRIN. 2009. "Adaptation to Oxidative

413 Stress and Impact of Chronic Oxidative Stress on Immunity in Heat-Stressed Broilers.”

414 Journal of Thermal Biology 34: 353-357. doi.org/10.1016/j.jtherbio.2009.06.003.

415 PAYNE, R.L., and L.L. SOUTHERN. 2005. "Comparison of Inorganic and Organic

416 Selenium Sources for Broilers.” Poultry Science 84: 898-902. doi.org/10.1093/ps/84.6.898.

417 PERIC, L., N., MILOSEVIC, D., ŽIKIC, Z., KANAACKI, N., DZINIC, L., NOLLET, and

418 P. SPRING. 2009. "Effect of Selenium Sources on Performance and Meat Characteristics

419 of Broiler Chickens.” Journal of Applied Poultry Research 18 (3): 403-409. doi:

$420 \quad$ 10.3382/japr.2008-00017.

421 PIRGOZLIEV, V., C. WESTBROOK, S. WOODS, M. R. KARAGECILI, F. KARADAS,

422 S. P. ROSE, and S. C. MANSBRIDGE. 2019. "Feeding Dihydroquercetin to Broiler

423 Chickens." British Poultry Science 60 (3): 241-245. doi.org

$424 \quad 10.1080 / 00071668.2018 .1556387$.

425 PlACHA, I., J., TAKACOVA, M., RYZNER, K., COBANOVA, A., LAUKOVA, V.,

426 STROMPFOVA, K., VENGLOVSKA, and S. FAIX. 2014. "Effect of Thyme Essential Oil

427 and Selenium on Intestine Integrity and Antioxidant Status of Broilers.” British Poultry

428 Science 55 (1): 105-114. doi.org/10.1080/00071668.2013.873772.

429 QUINTEIRO-FILHO, W.M., A., RIBEIRO, V., FERRAZ-DE-PAULA, M.L., PINHEIRO,

430 M., SAKAI, L.R.M.D., SA, A.J.P., FERREIRA, and J. PALERMO-NETO. 2010. "Heat

431 Stress Impairs Performance Parameters, Induces Intestinal Injury, and Decreases

432 Macrophage Activity in broiler chickens.” Poultry Science 89 (9): 1905-1914.

433 doi.org/10.3382/ps.2010-00812.

434 RICE-EVANS, C. and N.J. MILLER. 1994. "Total Antioxidant Status in Plasma and Body

435 Fluids.” In: Methods in Enzymology 234: 279-293. USA. Academic Press. 
436 SAHIN, N., M., ONDERCI, K., SAHIN, and O. KUCUK. 2008. "Supplementation with

437 Organic or Inorganic Selenium in Heat-Distressed Quail.” Biological Trace Element

438 Research 122: 229-237. doi.org/10.1007/s12011-007-8075-6.

439 SARICA, S., H., AYDIN, and G. CIFTCI. 2017. "Effects of Dietary Supplementation of

440 Some Antioxidants on Liver Antioxidant Status and Plasma Biochemistry Parameters of

441 Heat-Stressed Quail." Turkish Journal of Agriculture-Food Science and Technology 5 (7)

442 773-779. doi.org/10.24925/turjaf.v5i7.773-779.1182.

443 SIES, H., 2015. "Oxidative Stress: a Concept in Redox Biology and Medicine.” Redox

444 Biology 4: 180-183. doi.org/10.1016/j.redox.2015.01.002.

445 SURAI, P. F., 2002. "Selenium in Poultry Nutrition: Antioxidant Properties, Deficiency 446 and Toxicity." World Poultry Science Journal 58 (3): 333-347. 447 doi.org/10.1079/WPS20020026.

448 SURAI, P. F., 2006. Selenium in Nutrition and Health. Nottingham, Nottingham 449 University Press.

450 SURAI, P.F. AND V.I. FISININ. 2014. "Selenium in Poultry Breeder Nutrition: An 451 Update." Animal Feed Science and Technology 191: 1-15. 452 doi.org/10.1016/j.anifeedsci.2014.02.005.

453 TANNER, S.D., V.I., BARANOV, and D.R. BANDURA. 2002. "Reaction Cells and 454 Collison Cells for ICP-MS: a Tutorial Review." Spectrochimica Acta, Part B Atomic 455 Spectroscopy 57 (9): 1361-1452. doi.org/10.1016/S0584-8547(02)00069-1.

456 TEETER, R.G., 1996. “Optimizing Production of Heat Stressed Broilers.” Journal of 457 Agricultural and Marine Sciences 1: 129-137. doi.org/10.24200/jams.vol1iss0pp129-137.

458 VOLJC, M., T., FRANKIC, A., LEVART, M., NEMEC, and J. SALOBIR. 2011.

459 "Evaluation of Different Vitamin E Recommendations and Bioactivity of $\alpha$-Tocopherol

460 Isomers in Broiler Nutrition by Measuring Oxidative Stress in Vivo and the Oxidative

461 Stability of Meat.” Poultry Science 90: 1478-1488. doi.org/10.3382/ps.2010-01223. 
477

WANG, Y.B., and B.H. XU. 2008. "Effect of Different Selenium Source (Sodium Selenite and Selenium Yeast) on Broiler Chickens." Animal Feed Science and Technology 144: 306-314. doi.org/10.1016/j.anifeedsci.2007.10.012.

WANG, Z., Z., YING, A., BOSY-WESTPHAL, J., ZHANG, B., SCHAUTZ, W., LATER, S.B., HEYMSFIELD, and M. MULLER. 2010. "Specific Metabolic Rates of Major Organs and Tissues across Adulthood Evaluation by Mechanisitic Model of Resting Energy Expenditure." The American Journal of Clinical Nutrition 92 (6): 1369-1377. doi.org/10.3945/ajen.2010.29885.

WOODS, S. L., S. SOBOLEWSKA, S. P. ROSE, I. M. WHITING, A. BLANCHARD, C. IONESCU, D. BRAVO, and V. PIRGOZLIEV. 2020 "Effect of Feeding Different Sources of Selenium on Growth Performance and Antioxidant Status of Broilers." British Poultry Science just-accepted. doi.org/10.1080/00071668.2020.1716301.

WOLFFRAM, S. B., B., GRENACHER, and R. SCHARRER. 1989. "Transport of Selenoamino Acids and Their Sulphur Analogues across the Intestinal Brush Border Membrane.” Journal of Nutrition 119: 706-712. doi.org/10.1093/jn/119.5.706.

XU, S., S.H., LEE, H.S., LILLEHOJ, Y.H., HONG, and D. BRAVO. 2015. "Effects of Dietary Selenium on Host Response to Necrotic Enteritis in Young Broilers." Research in Veterinary Science, 98: 66-73. doi.org/10.1016/j.rvsc.2014.12.004.

YANG, Y.R., F.C., MENG, P., WANG, Y.B., JIANG, Q.Q., YIN, J., CHANG, R.Y., ZUO, Q.H., ZHENG, and J.X. LIU. 2012. "Effect of Organic and Inorganic Selenium Supplementation on Growth Performance, Meat Quality and Antioxidant Properties of Broilers." African Journal of Biotechnology $11 \quad$ (12): 3031-3036. doi.org/10.5897/AJB11.3382. 
490 Table 1. Ingredient composition of the basal diets (as fed) to broilers.

Ingredients $\mathrm{g} / \mathrm{kg}$

491

Wheat

Soybean meal 48

Vegetable oil

Salt

DL Methionine

Lysine $\mathrm{HCl}$

Limestone

Dicalcium Phosphate

Vitamin Mineral premix ${ }^{1}$

Calculated values (as fed)

Crude protein $(\mathrm{N} \times 6.25 \mathrm{~g} / \mathrm{kg})$

Crude oil g/kg

$\mathrm{ME}, \mathrm{MJ} / \mathrm{kg}$

Calcium $\mathrm{g} / \mathrm{kg}$

Av phosphorus g/kg

492

Determined values (as fed)

Dry matter $\mathrm{g} / \mathrm{kg}$

Crude protein $(\mathrm{N} \times 6.25 \mathrm{~g} / \mathrm{kg})$

Crude oil g/kg

Selenium $\mathrm{mg} / \mathrm{kg}$
Starter

0 to $14 d$

606.5

317.0

35.0

3.0

3.7

1.8

10.0

18.0

5.0
629.5

5.0

Finisher 14 to $35 d$

280.0

50.0

3.0

3.9

1.6

10.0

17.0
229.9

214.9

46.5

61.4

12.67

13.11

9.3

9.0

4.7

4.5
870

249.7

45.7

0.224
877

240.1

60.2

2 
$494{ }^{1}$ The vitamin and mineral premix contained vitamins and trace elements to meet

495 requirements specified by NRC (1994) except diets for experimental finisher diets which

496 varied in Se. The premix provided (units per kg/diet): cholecalciferol $125 \mu \mathrm{g}$; retinol 3000

$497 \mu \mathrm{g}$; $\alpha$-tocopherol $30 \mathrm{mg}$; riboflavin $10 \mathrm{mg}$; pantothenic acid $15 \mathrm{mg}$; cobalt $0.5 \mathrm{mg}$;

498 molybdenum $0.48 \mathrm{mg}$; cyanocobalamin $30 \mathrm{mg}$; pyridoxine $3 \mathrm{mg}$; thiamine $3 \mathrm{mg}$; folic acid

$4991.5 \mathrm{mg}$; niacin $60 \mathrm{mg}$; biotin $0.25 \mathrm{mg}$; iodine $1 \mathrm{mg}$; copper $10 \mathrm{mg}$; iron $20 \mathrm{mg}$; manganese

$500100 \mathrm{mg}$; zinc $80 \mathrm{mg}$.

$501{ }^{2}$ Se in finisher diets:- C: $0.189 \mathrm{mg} / \mathrm{kg}$; LSS: low level sodium selenite $(0.376 \mathrm{mg} / \mathrm{kg})$;

502 HSS: high level sodium selenite $(0.558 \mathrm{mg} / \mathrm{kg})$; LBT: low level B Traxim ${ }^{\circledR}(0.244 \mathrm{mg} / \mathrm{kg})$;

503 HBT: high level B Traxim ${ }^{\circledR}(0.448 \mathrm{mg} / \mathrm{kg})$

504 LSY: low level selenised yeast $(0.290 \mathrm{mg} / \mathrm{kg})$; HSY: high level selenised yeast $(0.487$

$505 \mathrm{mg} / \mathrm{kg})$.

506

507

Table 2. The effect of dietary selenium source and level on daily feed intake; weight gain

508 and feed conversion efficiency (FCE) of broilers at 14-35 d age, comparing temperature;

509 diets; level; temperature x level and diets x level interactions.

510

\begin{tabular}{|c|c|c|c|}
\hline Treatment factor & $\begin{array}{c}\mathrm{F} / \mathrm{I} \\
(\mathrm{g} / \mathrm{b} / \mathrm{d})\end{array}$ & $\begin{array}{l}\text { WG } \\
(\mathrm{g} / \mathrm{b} / \mathrm{d})\end{array}$ & $\begin{array}{l}\text { FCE } \\
(\mathrm{g} / \mathrm{g})\end{array}$ \\
\hline & $14-35 d$ & $14-35 d$ & $14-35 d$ \\
\hline \multicolumn{4}{|l|}{ Temperature } \\
\hline Standard & 114.9 & 75.6 & 0.664 \\
\hline High & & 56.6 & 0.636 \\
\hline SEM & 0.85 & 1.06 & 0.0101 \\
\hline \multicolumn{4}{|l|}{ Diets } \\
\hline Control (C) & $103.2^{\mathrm{ab}}$ & $67.1^{\mathrm{a}}$ & $0.653^{\mathrm{a}}$ \\
\hline Sodium Selenite (SS) & $103.1^{\mathrm{ab}}$ & $67.6^{\mathrm{a}}$ & $0.656^{\mathrm{a}}$ \\
\hline B-TRAXIM $^{\circledR}(\mathrm{BT})$ & $103.5^{\mathrm{a}}$ & $67.0^{\mathrm{a}}$ & $0.654^{\mathrm{a}}$ \\
\hline Selenised yeast (SY) & $99.7^{\mathrm{b}}$ & $63.2^{\mathrm{b}}$ & $0.639^{\mathrm{b}}$ \\
\hline SEM & 0.94 & 0.93 & 0.0033 \\
\hline Low inclusion level & 102.7 & 66.8 & 0.653 \\
\hline High inclusion level & 101.8 & 65.3 & 0.647 \\
\hline SEM & 0.86 & 0.81 & 0.0036 \\
\hline \multicolumn{4}{|l|}{ Temperature x Level } \\
\hline Low inclusion level $20^{\circ} \mathrm{C}$ & 114.0 & 74.8 & 0.663 \\
\hline High inclusion level $20^{\circ} \mathrm{C}$ & 115.7 & 76.3 & 0.664 \\
\hline Low inclusion level $35^{\circ} \mathrm{C}$ & 91.3 & 58.9 & 0.632 \\
\hline High inclusion level $35^{\circ} \mathrm{C}$ & 88.0 & 54.3 & 0.636 \\
\hline SEM & 1.24 & 1.36 & 0.0133 \\
\hline \multicolumn{4}{|l|}{ Diets x Level } \\
\hline LSS & 104.2 & 68.2 & 0.655 \\
\hline HSS & 101.9 & 67.0 & 0.658 \\
\hline LBT & 104.0 & 67.7 & 0.658 \\
\hline HBT & 102.9 & 66.3 & 0.649 \\
\hline LSY & 99.3 & 64.1 & 0.644 \\
\hline HSY & 100.1 & 62.2 & 0.634 \\
\hline SEM & 1.50 & 1.41 & 0.0063 \\
\hline \multicolumn{4}{|l|}{ Probabilities } \\
\hline Temperature & 0.030 & 0.050 & 0.187 \\
\hline
\end{tabular}




\begin{tabular}{lccc} 
Diets & 0.045 & 0.008 & 0.041 \\
Level & 0.820 & 0.462 & 0.566 \\
Temperature x Diet & 0.558 & 0.130 & 0.305 \\
Temperature x Level & 0.117 & 0.032 & 0.824 \\
Diets x Level & 0.28 & 0.76 & 0.245 \\
CV \% & 5.8 & 8.4 & 3.9 \\
\hline
\end{tabular}

C: $0.189 \mathrm{mg} / \mathrm{kg}$

513 LSS: low level sodium selenite $(0.376 \mathrm{mg} / \mathrm{kg})$

514 HSS: high level sodium selenite $(0.558 \mathrm{mg} / \mathrm{kg})$

515 LBT: low level B $\operatorname{Traxim}^{\circledR}(0.244 \mathrm{mg} / \mathrm{kg})$

516 HBT: high level B Traxim ${ }^{\circledR}(0.448 \mathrm{mg} / \mathrm{kg})$

517 LSY: low level selenised yeast $(0.290 \mathrm{mg} / \mathrm{kg})$

518 HSY: high level selenised yeast $(0.487 \mathrm{mg} / \mathrm{kg})$.

519 a,b,c significance between treatments determined by ANOVA.

520 Means within a column with no common superscript differ significantly $(P<0.50)$.

521 CV \%: coefficient of variation. SEM: standard error of mean. Each diet fed to birds in 16 522 pens

Table 3. The effect of dietary selenium (Se) source and level on glutathione peroxidase (GSH-Px); total antioxidant status (TAS); Se levels in breast and liver tissue of broilers comparing temperature; diets; level; and diets $\mathrm{x}$ level interactions.

\begin{tabular}{|c|c|c|c|c|c|c|}
\hline Treatment factor & $\begin{array}{l}\text { SH-Px } \\
(\mathrm{u} / \mathrm{ml} \\
\mathrm{RBC})\end{array}$ & $\begin{array}{c}\text { TAS } \\
(\mathrm{mmol} / \mathrm{l})\end{array}$ & $\begin{array}{c}\text { Se breast } \\
\mathrm{mg} / \mathrm{Kg} \\
\mathrm{DM}\end{array}$ & $\begin{array}{l}\text { Breast } \\
\text { DM } \\
\text { Kg/ kg }\end{array}$ & $\begin{array}{l}\text { Se liver } \\
\mathrm{mg} / \mathrm{kg} \\
\mathrm{DM}\end{array}$ & $\begin{array}{l}\text { Liver } \\
\mathrm{DM} \\
\mathrm{Kg} / \mathrm{kg}\end{array}$ \\
\hline \multicolumn{7}{|l|}{ Temperature } \\
\hline Standard & 81 & 1.15 & 0.75 & 0.257 & 2.35 & 0.277 \\
\hline High & 85 & 1.40 & 0.74 & 0.255 & 1.96 & 0.303 \\
\hline SEM & 2.8 & 0.183 & 0.012 & 0.0043 & 0.109 & 0.0056 \\
\hline Control (C) & $48^{\mathrm{a}}$ & 1.19 & $0.59^{\mathrm{a}}$ & 0.256 & $1.66^{\mathrm{a}}$ & 0.294 \\
\hline Sodium Selenite & & 1.26 & $0.66^{\mathrm{b}}$ & 0.256 & $2.24^{\mathrm{bc}}$ & 0.286 \\
\hline$(\mathrm{SS})$ & $105^{\mathrm{b}}$ & & & & & \\
\hline B-TRAXIM $^{\circledR}(\mathrm{BT})$ & $81^{\mathrm{c}}$ & 1.27 & $0.66^{\mathrm{b}}$ & 0.255 & $2.16^{\mathrm{b}}$ & 0.291 \\
\hline Selenised & & 1.30 & $0.99^{c}$ & 0.255 & $2.32^{\mathrm{c}}$ & 0.291 \\
\hline$(\mathrm{SY})$ & $81^{\mathrm{c}}$ & & & & & \\
\hline SEM & 4.8 & 0.053 & 0.015 & 0.0019 & 0.037 & 0.0044 \\
\hline \multicolumn{7}{|l|}{ Level } \\
\hline inclusion & & 1.29 & 0.70 & 0.255 & 2.05 & 0.292 \\
\hline level & 74 & & & & & \\
\hline inclusion & & 1.27 & 0.79 & 0.256 & 2.27 & 0.288 \\
\hline level & 92 & & & & & \\
\hline SEM & 4.0 & 0.040 & 0.008 & 0.0016 & 0.038 & 0.0036 \\
\hline \multicolumn{7}{|l|}{ Diets x Level } \\
\hline LSS & 90 & 1.22 & 0.65 & 0.256 & 2.17 & 0.287 \\
\hline HSS & 120 & 1.30 & 0.68 & 0.257 & 2.32 & 0.284 \\
\hline
\end{tabular}

Accepted for publication 22 April 2020 


\begin{tabular}{lcccccc} 
LBT & 75 & 1.39 & 0.65 & 0.252 & 2.08 & 0.290 \\
HBT & 87 & 1.16 & 0.66 & 0.258 & 2.24 & 0.292 \\
LSY & 75 & 1.25 & 0.87 & 0.257 & 2.16 & 0.296 \\
HSY & 87 & 1.35 & 1.11 & 0.253 & 2.49 & 0.286 \\
SEM & 6.7 & 0.069 & 0.014 & 0.0027 & 0.066 & 0.0062 \\
Probabilities & & & & & & \\
Temperature & 0.444 & 0.440 & 0.757 & 0.777 & 0.127 & 0.081 \\
Diets & $<0.001$ & 0.592 & $<0.001$ & 0.940 & $<0.001$ & 0.678 \\
Level & 0.006 & 0.997 & $<0.001$ & 0.887 & $<0.001$ & 0.771 \\
Temperature x Diet & 0.415 & 0.765 & 0.158 & 0.444 & 0.380 & 0.383 \\
Temperature x Level & 0.161 & 0.429 & 0.971 & 0.883 & 0.939 & 0.519 \\
Diets x Level & 0.128 & 0.031 & $<0.001$ & 0.082 & 0.135 & 0.365 \\
CV \% & 32.5 & 21.5 & 7.6 & 4.2 & 12.3 & 8.6 \\
\hline
\end{tabular}

529 C: $0.189 \mathrm{mg} / \mathrm{kg}$

530 LSS: low level sodium selenite $(0.376 \mathrm{mg} / \mathrm{kg})$

531 HSS: high level sodium selenite $(0.558 \mathrm{mg} / \mathrm{kg})$

532 LBT: low level B Traxim ${ }^{\circledR}(0.244 \mathrm{mg} / \mathrm{kg})$

533 HBT: high level B Traxim ${ }^{\circledR}(0.448 \mathrm{mg} / \mathrm{kg})$

534 LSY: low level selenised yeast $(0.290 \mathrm{mg} / \mathrm{kg})$

535 HSY: high level selenised yeast $(0.487 \mathrm{mg} / \mathrm{kg})$.

536 a,b,c significance between treatments determined by ANOVA.

537 Means within a column with no common superscript differ significantly $(P<0.50)$.

538 CV \%: coefficient of variation. SEM: standard error of mean. Each diet fed to birds in 16 539 pens

540 